\title{
Origanum vulgare Terpenoids Induce Oxidative Stress and Reduce the Feeding Activity of Spodoptera littoralis
}

\author{
Chiara Agliassa and Massimo E. Maffei * \\ Department Life Sciences and Systems Biology, University of Turin, Via G. Quarello 15/a, 10135 Turin, Italy; \\ chiara.agliassa@unito.it \\ * Correspondence: massimo.maffei@unito.it; Tel.: +39-011-670-5967
}

Received: 31 August 2018; Accepted: 15 September 2018; Published: 18 September 2018

\begin{abstract}
Terpenoids are toxic compounds produced by plants as a defense strategy against insect herbivores. We tested the effect of Origanum vulgare terpenoids on the generalist herbivore Spodoptera littoralis and the response of the plant to herbivory. Terpenoids were analyzed by GC-FID and GC-MS and quantitative gene expression (qPCR) was evaluated on selected plant genes involved in both terpene biosynthesis. The insect detoxification response to terpenes was evaluated by monitoring antioxidant enzymes activity and expression of insect genes involved in terpene detoxification. $O$. vulgare terpenoid biosynthesis and gene expression was modulated by $S$. littoralis feeding. The herbivore-induced increased level of terpenoids (particularly carvacrol and $p$-cymene) interacted with the herbivore by decreasing larval survival and growth rate. The assimilation by S. littoralis of more than $50 \%$ of ingested terpenes correlated with the possible toxic effects of O. vulgare terpenoids. In choice test experiments, carvacrol and $\gamma$-terpinene mediated the larval feeding preferences, wherease the prolonged feeding on $O$. vulgare terpenoids (particularly on $\gamma$-terpinene) exerted relevant antinutritional effects on larvae. S. littoralis was found to react to $O$. vulgare terpenoids by increasing its antioxidant enzymes activities and gene expression, although this was not sufficient to sustain the toxicity of $O$. vulgare terpenoids.
\end{abstract}

Keywords: Origanum vulgare; Spodoptera littoralis; terpenoid biosynthesis; larval survival; antioxidant enzyme activity and gene expression; toxicity

\section{Introduction}

Terpenoids constitute the largest and most heterogeneous class of secondary metabolites, and include monoterpenes and sesquiterpenes as volatile constituents [1,2]. These volatile terpenoids can act both as constitutive and herbivory-induced (Herbivore-Induced Plant Volatiles, HIPVs) defense compounds. Moreover, HIPVs can be emitted either at the site of damage or systemically from undamaged parts of affected plants [3]. Constitutive accumulation of terpenoids occurs in specialized tissues, such as the glandular trichomes [4], which are present in aromatic plants and act as direct defense against herbivores through either a toxic or deterrent activity [5]. In the Lamiaceae family, oregano (Origanum vulgare L.) is characterized by large peltate glandular trichomes that accumulate monoterpenes and sesquiterpenes $[4,6,7]$. The main terpenes are the two phenolic monoterpenes: Thymol and carvacrol [8-10]. These terpenoids are physiologically toxic towards insect larvae [11]. Phytophagous insects represent one of the major causes of biotic stress for plants [12] and herbivore attack can cause both quantitative and qualitative changes in the composition of HIPVs [2,13-15]. Monoterpenes such as thymol and carvacrol show $\mathrm{LD}_{50}$ values of 25 and $43 \mu \mathrm{g} \cdot$ larvae $^{-1}$, respectively, when tested on early four-instar Spodoptera litura and the $\mathrm{LD}_{50}$ of these monoterpenes increases with 
the larval development [16]. The toxicity of these monoterpenes is higher versus Spodoptera littoralis, Plutella xylostella, Callosobruchus maculatus and Culex quinquefasciatus, with $\mathrm{LD}_{50}$ values as low as $0.22 \mu \mathrm{g} \cdot$ larvae $^{-1}$ [17-21], whereas thymol and carvacrol toxicity versus Sitophilus granarius is lower, with $\mathrm{LD}_{50}$ above $100 \mu \mathrm{g} \cdot \mathrm{larvae}^{-1}$ [22,23]. Toxic synergistic effects of thymol and carvacrol with other monoterpenes have been also described [24]. The mode of action of these monoterpenes on herbivores is not fully understood, although they have been found to elicit insect detoxification enzymes $[21,25,26]$ and other mechanisms of tolerance [27].

The objective of this work was to study the response of the generalist herbivore Spodoptera littoralis to Origanum vulgare terpenoids. To this aim, we analyzed O. vulgare volatile terpenoids before and after herbivore feeding and evaluated their toxicity by insect exposure during feeding, while the terpenoid deterrent and anti-nutritional effects were tested by behavioral assays. Finally, the detoxification mechanisms of $S$. littoralis towards $O$. vulgare terpenes were also studied.

\section{Results}

\subsection{O. vulgaris Terpenoids are Modulated by S. littoralis Herbivory}

The volatile profile of $O$. vulgare undamaged leaves is characterized by the presence of several monoterpenes and sesquiterpenes (Table 1). In general, herbivory increased the total terpene content of $O$. vulgare leaves; however, the qualitative composition of terpenoids was not changed (Table 1). In particular, herbivore wounded (HW) O. vulgare plants showed a significant increase of two green leaf volatiles, (E)-2-hexenal and (Z)-3-hexenol, with respect to control undamaged plants. With regards to monoterpenes, HW significantly increased the content of $\alpha$-terpinene, limonene, $\beta$-phellandrene, trans-sabinene hydrate, cis-sabinene hydrate, linalool, linalool oxide, $\alpha$-terpineol, trans-dihydrocrvone, cis-dihydrocarvone, carvacrol methyl ether, linalyl acetate and thymol, with respect to controls. No significant difference was found for the remaining monoterpenes, including the major compound carvacrol (Table 1). Considering the sesquiterpenes, herbivory significantly increased the content of almost all identified compounds, with the exception of $\alpha$-copaene, $\alpha$-humulene and trans-farnesol (Table 1).

We then assessed the expression of some genes involved in $O$. vulgare terpenoid biosynthesis. Upon herbivory, a strong upregulation was found for O. vulgare CYP71D180, which was followed by a 4-fold upregulation of GPPS and an approximate 2-fold upregulation of DXS. TPS2 showed minor upregulation after HW. CYP71D178, CYP71D179 and CYP1D181 were slightly downregulated by $S$. littoralis feeding activity (Figure 1).

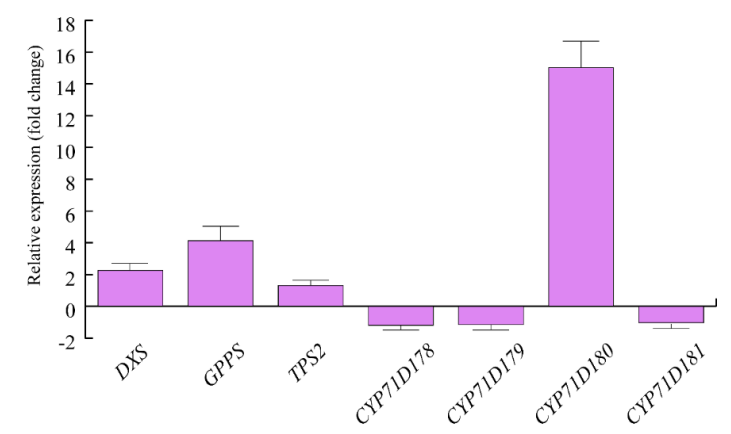

Figure 1. Levels of gene expression in Origanum vulgare leaves upon Spodoptera littoralis herbivory. Data are expressed as fold change (herbivory vs. control). CYP71D180 = one of the 4 cytochrome P450 isoforms possibly involved in carvacrol biosythesis, isolated from O. vulgare; TPS2: $\gamma$-terpinene synthase, isolated from $O$. vulgare and involved in the production of several monoterpenes, including the potential precursors of carvacrol; CYP71D178 and CYP71D179 = cytochrome P450 isoforms possibly involved in carvacrol biosynthesis, isolated from O. vulgare; DXS: Deoxyxylulose phosphate synthase; GPPS: Geranyldiphosphate synthase. Three technical replicates were run for each biological replicate. Metric bars indicate standard deviation. 
Table 1. Chemical composition of Origanum vulgare terpenoids in undamaged control plants, in Spodoptera littoralis herbivore wounded (HW) plants and in S. littoralis frass upon feeding on $O$. vulgare leaves. The results are expressed as $\mu \mathrm{g} \mathrm{g}^{-1}$ fresh weight and are the mean of at least three replicates $\pm \mathrm{SD}$. Asterisks indicate significant differences between control and HW: ${ }^{*} p<0.05$; ** $p<0.01$.

\begin{tabular}{|c|c|c|c|}
\hline Compounds & Control & HW & Frass \\
\hline \multicolumn{4}{|l|}{ Green Leaf Volatiles } \\
\hline (E)-2-Hexenal & nd & $8.96 \pm 3.66^{* *}$ & nd \\
\hline (Z)-3-Hexenol & nd & $9.43 \pm 0.79^{* *}$ & nd \\
\hline \multicolumn{4}{|l|}{ Monoterpenes } \\
\hline Sabinene & $116.32 \pm 0.24$ & $133.99 \pm 8.09$ & $2.84 \pm 0.34$ \\
\hline$\beta$-Pinene & $4.18 \pm 0.03$ & $4.75 \pm 0.56$ & nd \\
\hline$\beta$-Myrcene & $31.93 \pm 1.00$ & $34.61 \pm 1.88$ & $0.42 \pm 0.04$ \\
\hline$\alpha$-Terpinene & $25.62 \pm 0.5$ & $32.38 \pm 2.30 *$ & $0.77 \pm 0.12$ \\
\hline$p$-Cymene & $53.87 \pm 18.84$ & $83.43 \pm 10.39$ & $2.97 \pm 0.60$ \\
\hline 1-Octen-3-ol & $5.12 \pm 0.31$ & $13.75 \pm 3.67$ & nd \\
\hline Limonene & $14.55 \pm 2.13$ & $20.21 \pm 0.05 *$ & nd \\
\hline$\beta$-Phellandrene & $17.91 \pm 1.36$ & $28.83 \pm 2.95^{*}$ & nd \\
\hline$\gamma$-Terpinene & $187.89 \pm 1.61$ & $193.92 \pm 15.28$ & $8.60 \pm 1.17$ \\
\hline 1-Octenyl-3-acetate & $20.01 \pm 0.93$ & $24.75 \pm 4.29$ & nd \\
\hline Trans-sabinene hydrate & $52.28 \pm 5.31$ & $98.07 \pm 10.80^{* *}$ & $1.41 \pm 0.32$ \\
\hline Cis-sabinene hydrate & $700.21 \pm 71.55$ & $1062.03 \pm 167.15^{* *}$ & $19.38 \pm 1.53$ \\
\hline Linalool & $7.40 \pm 0.49$ & $17.79 \pm 0.62 *$ & nd \\
\hline Linalool oxide & $4.33 \pm 0.15$ & $6.90 \pm 0.74$ & nd \\
\hline Terpinen-4-ol & $8.12 \pm 0.86$ & $10.78 \pm 2.03$ & $1.16 \pm 0.16$ \\
\hline$\alpha$-Terpineol & $43.64 \pm 4.56$ & $60.50 \pm 11.09 *$ & $1.80 \pm 0.20$ \\
\hline Trans-dihydrocarvone & $4.04 \pm 0.28$ & $5.88 \pm 0.23^{* *}$ & nd \\
\hline Cis-dihydrocarvone & $9.20 \pm 0.56$ & $12.70 \pm 1.68 *$ & $1.57 \pm 0.29$ \\
\hline Sabinene hydrate acetate & $5.59 \pm 0.09$ & $6.76 \pm 1.11$ & nd \\
\hline Carvacrol methyl ether & $44.29 \pm 1.77$ & $86.34 \pm 5.03^{* *}$ & $3.35 \pm 0.44$ \\
\hline Linalyl acetate & $51.03 \pm 3.11$ & $88.85 \pm 10.51^{* *}$ & $2.45 \pm 0.18$ \\
\hline Thymol & $4.11 \pm 0.33$ & $6.92 \pm 0.32^{* *}$ & nd \\
\hline Carvacrol & $959.26 \pm 8.90$ & $1159.39 \pm 84.46$ & $109.76 \pm 6.96$ \\
\hline \multicolumn{4}{|l|}{ Sesquiterpenes } \\
\hline Bicycloelemene & $11.49 \pm 1.54$ & $18.95 \pm 1.32 *$ & nd \\
\hline$\beta$-Cubebene & $5.99 \pm 0.92$ & $12.13 \pm 0.03^{* *}$ & nd \\
\hline$\alpha$-Copaene & $10.93 \pm 1.31$ & $7.73 \pm 2.10$ & nd \\
\hline$\beta$-Caryophyllene & $40.81 \pm 2.66$ & $58.38 \pm 5.43 *$ & $1.69 \pm 0.29$ \\
\hline$\alpha$-Humulene & $5.65 \pm 1.04$ & $7.65 \pm 0.20$ & nd \\
\hline Germacrene D & $37.19 \pm 2.72$ & $49.46 \pm 2.96^{*}$ & $1.79 \pm 0.37$ \\
\hline Bicyclogermacrene & $24.05 \pm 3.32$ & $33.18 \pm 2.12^{*}$ & $1.13 \pm 0.12$ \\
\hline$\beta$-Bisabolene & $93.00 \pm 7.33$ & $114.85 \pm 4.94$ * & $5.33 \pm 0.93$ \\
\hline$\alpha$-Farnesene & $2.54 \pm 0.16$ & $6.44 \pm 0.59 *$ & nd \\
\hline$\beta$-Sesquiphellandrene & $6.91 \pm 0.92$ & $12.71 \pm 0.80^{* *}$ & nd \\
\hline Germacrene D-4-ol & $4.14 \pm 0.50$ & $7.18 \pm 1.10 *$ & nd \\
\hline Trans-farnesol & $3.94 \pm 0.07$ & $4.07 \pm 0.38$ & $0.81 \pm 0.15$ \\
\hline TOTAL & $2617.54 \pm 27.15$ & $3544.65 \pm 66.13$ & $163.16 \pm 6.58$ \\
\hline
\end{tabular}

$\mathrm{nd}$, not detectable indicates values below the limit of detection $\left(\mathrm{LOD}=0.1 \mu \mathrm{g} \cdot \mathrm{g}^{-1}\right)$.

\subsection{O. vulgaris Terpenoids Exert Toxic Effects on S. littoralis larvae}

Having assessed the ability of $O$. vulgare to respond to $S$. littoralis feeding by modulating terpenoid biosynthesis and gene expression, we tested the effect of $O$. vulgare terpenoids on S. littoralis larvae. After several trials we found that the 2nd and 3rd instar larvae showed a higher sensitivity to O. vulgare terpenoids; therefore, we used these two instar stages for all tests and measurements were performed during transition from one instar to the next one. Feeding on O. vulgare leaves caused a significantly $(p<0.05)$ lower survival percentage of $S$. littoralis larvae, with respect to the artificial diet (ACD) 
(Figure 2A). When larvae were offered a diet containing the O. vulgare terpenoid extract, a significant reduction of larvae survival was found with respect to ACD + Tween 20 (Figure 2B). We preliminary tested the effects of several $O$. vulgare terpenoids and we found that carvacrol (the major terpenoid of $O$. vulgare, Table 1$)$ and $p$-cymene induced a significant $(p<0.05)$ reduction of survival percentage with respect to ACD + Tween 20, whereas the effect of $\gamma$-terpinene (the precursor of carvacrol) was not different from controls (Figure 2B).

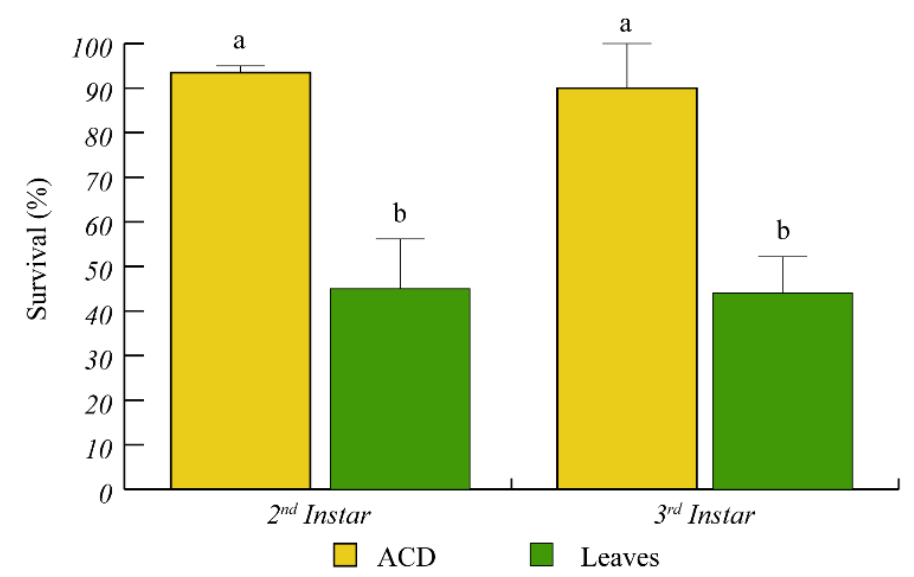

(A)

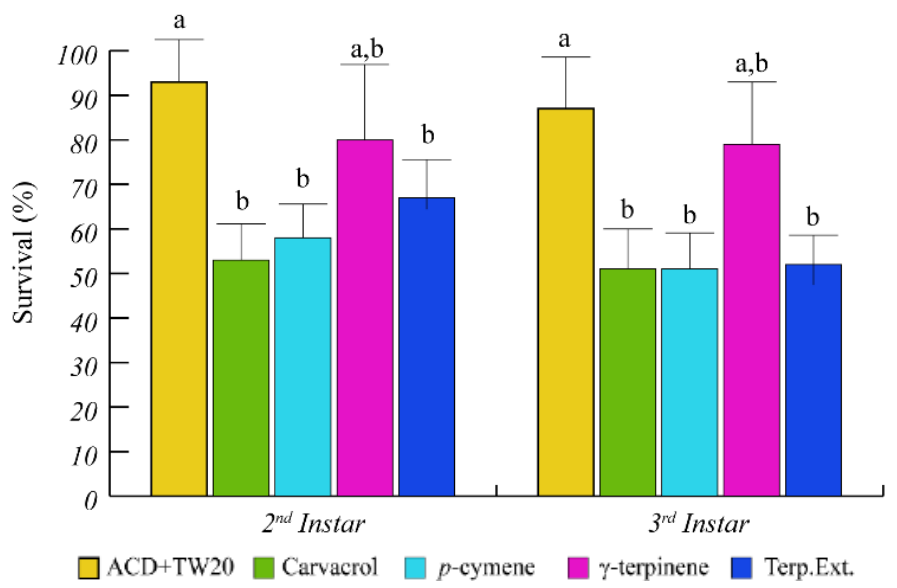

(B)

Figure 2. Percentage of $S$. littoralis survival upon feeding on O. vulgare leaves and terpenoids. (A) Comparison of $S$. littoralis survival upon feeding on artificial diet (ACD) or O. vulgare leaves. (B) Effect of terpenes extracted from O. vulgare leaves and of some O. vulgare monoterpenes on S. littoralis survival. ACD + Tween 20 was used as control. Bars indicate standard deviation. Different letters indicate significant $(p<0.05)$ differences.

O. vulgare terpenoids also affected the larval weight with a significant $(p<0.05)$ weight reduction, with respect to ACD (Figure 3). In particular, during the larval development from the 2nd to the 3 rd instar, the caterpillar weight increased less rapidly in caterpillars feeding on $O$. vulgare leaves, with respect to controls (Figure 3A). Caterpillars feeding on $\gamma$-terpinene and on O. vulgare terpenoid extracts showed a significant $(p<0.05)$ weight reduction with respect to ACD + Tween 20 (Figure 3B), whereas neither carvacrol nor $p$-cymene affected the larvae weight (Figure 3B). 


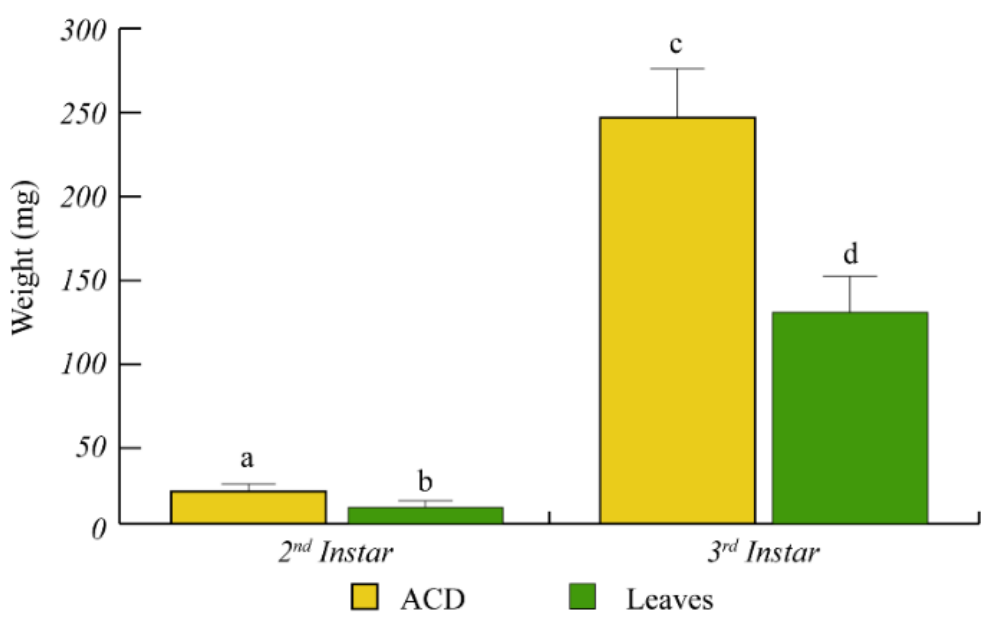

(A)

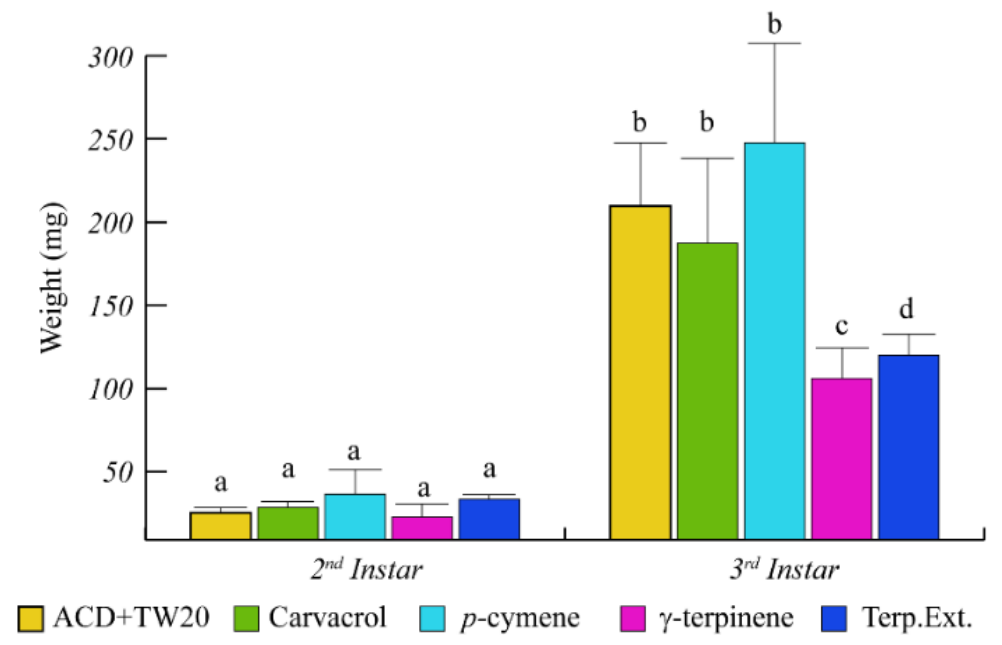

(B)

Figure 3. Weight variation of $S$. littoralis upon feeding on O. vulgare leaves and terpenoids. (A). Comparison of S. littoralis weight upon feeding on ACD or O. vulgare leaves. (B). Effect of terpenes extracted from $O$. vulgare leaves and some monoterpenes produced by O. vulgare on S. littoralis weight. ACD + Tween 20 was used as control. Bars indicate standard deviation. Different letters indicate significant $(p<0.05)$ differences.

To better assess the effects of $O$. vulgare terpenoids on S. littoralis growth, the increase of larval size was also monitored (Figure 4). Feeding of S. littoralis on O. vulgare leaves was ineffective on larvae size during the 2nd instar. However, a significant size reduction was found at the 3rd instar, with respect to controls (Figure 4A). As for the larvae weight increase, $\gamma$-terpinene and the O. vulgare terpenoids extracts were the only treatments that were able to significantly reduce the larvae size, with respect to ACD + Tween 20 (Figure 4B).

\subsection{Priming of S. littoralis with O. vulgare Terpenoids Induces Different Choice Behaviors}

We then compared the behavior of $S$. littoralis larvae with different feeding experience on $O$. vulgare leaves or ACD with O. vulgare terpenoids. In starved S. littoralis larvae, a significantly $(p<0.01)$ higher percentage of feed consumption was found when leaves were offered as the only feed source with respect to ACD (Figure 5a). However, when larvae were first fed with the ACD (ACD experienced), they significantly $(p<0.05)$ preferred to feed on ACD, with respect to leaves. However, larvae previously feeding on leaves (Leaf experienced) did not feed on ACD and consumed a significantly $(p<0.05)$ lower percentage of leaves, with respect to starved larvae (Figure $5 a)$. We then 
evaluated the effect of the individual $O$. vulgare monoterpenes on larvae choice tests. Starved larvae significantly $(p<0.05)$ preferred to feed on ACD when offered as the only feed source with respect to $\mathrm{ACD}+$ carvacrol (Figure $5 \mathrm{~b}$ ) and the same results were found on ACD experienced larvae. However, carvacrol experienced larvae did not feed on ACD and significantly $(p<0.05)$ preferred to feed on ACD + carvacrol (Figure $5 b$ ). In the choice test using $\gamma$-terpinene, starved larvae did not show any significant difference in preference between $\mathrm{ACD}$ and $\mathrm{ACD}+\gamma$-terpinene; however, both $\mathrm{ACD}$ experienced and $\gamma$-terpinene experienced larvae did not feed on ACD (Figure 5c). Finally, staved larvae preferentially fed on ACD with respect to ACD + p-cymene, whereas ACD experienced larvae fed preferentially on $\gamma$-terpinene. However, larvae experiencing $\gamma$-terpinene preferred to feed on ACD (Figure $5 \mathrm{~d}$ ).

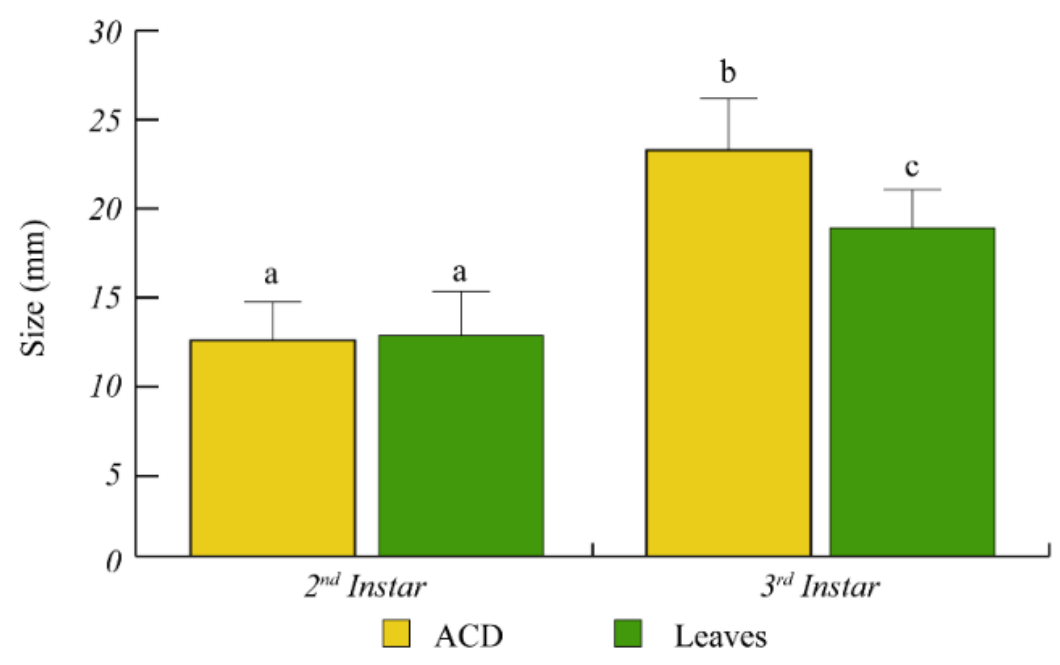

(A)

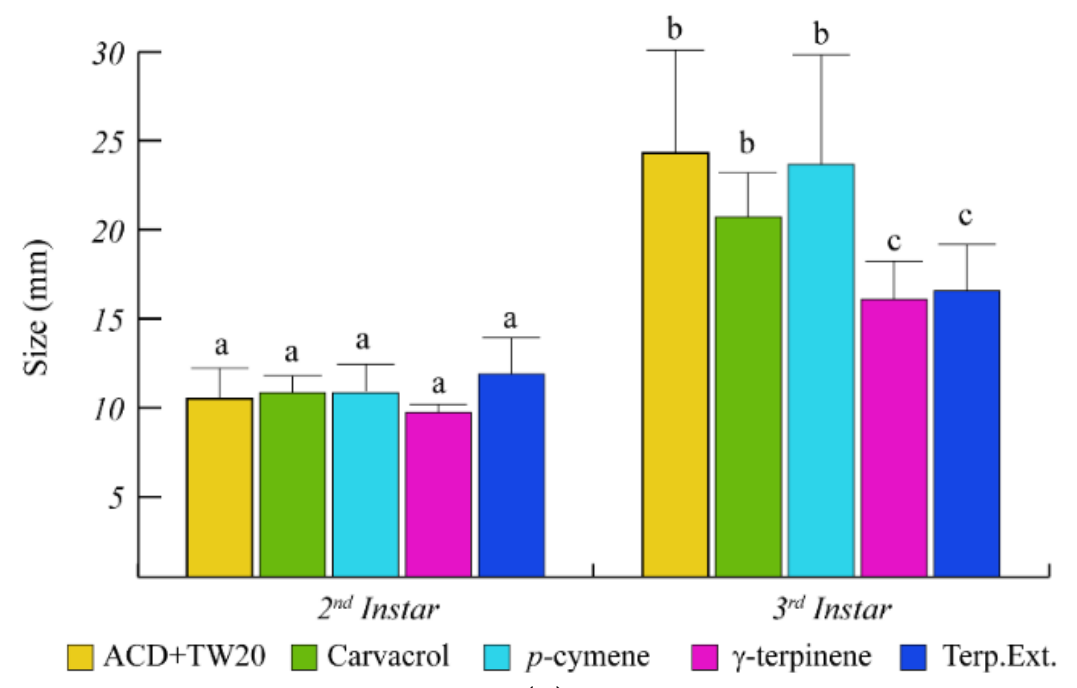

(B)

Figure 4. Larvae size of $S$. littoralis upon feeding on O. vulgare leaves and terpenoids. (A). Comparison of S. littoralis larvae size upon feeding on ACD or O. vulgare leaves. (B). Effect of terpenes extracted from $O$. vulgare leaves and some monoterpenes produced by $O$. vulgare on S. littoralis larvae size. ACD + Tween 20 was used as control. Bars indicate standard deviation. Different letters indicate significant $(p<0.05)$ differences. 


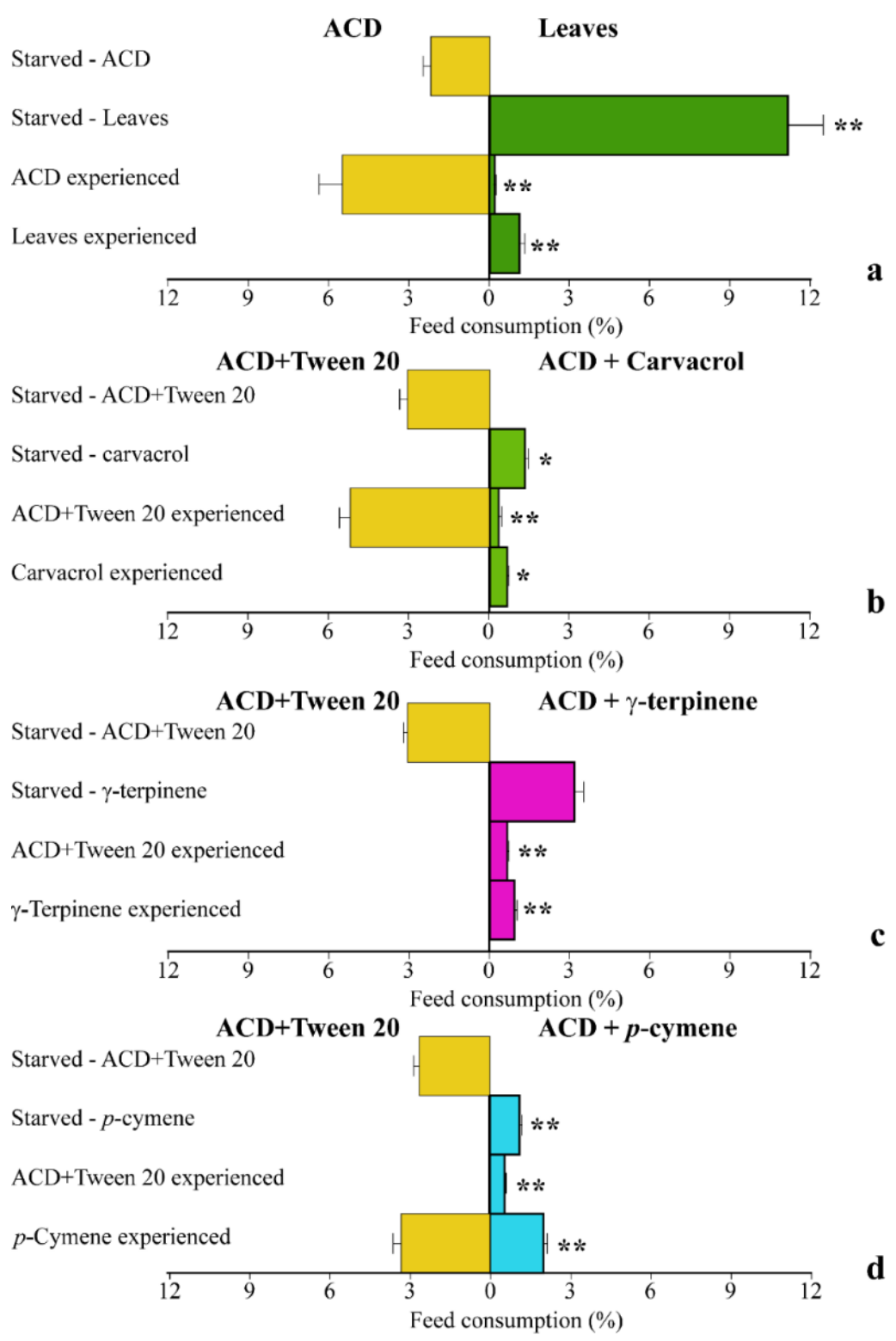

Figure 5. Behavior of $S$. littoralis upon feeding on $O$. vulgare leaves and terpenoids. (a). Response of $S$. littoralis starved larvae feeding on either ACD or O. vulgaris leaves along with feed preferences in larvae experiencing a previous nutrition with either ACD or O. vulgare leaves. (b). Response of S. littoralis starved larvae feeding on either ACD or ACD + carvacrol along with feed preferences in larvae experiencing a previous nutrition with either ACD or ACD + carvacrol. (c). Response of S. littoralis starved larvae feeding on either ACD or ACD $+\gamma$-terpinene along with feed preferences in larvae experiencing a previous nutrition with either ACD or ACD $+\gamma$-terpinene. (d). Response of S. littoralis starved larvae feeding on either ACD or ACD + p-cymene along with feed preferences in larvae experiencing a previous nutrition with either ACD or ACD + p-cymene. Results are expressed as the percentage of feed consumption. Values are the mean of at least three replicates; metric bars indicate standard deviation. Statistical difference is indicated by asterisks: ${ }^{*} p<0.05,{ }^{* *} p<0.01$.

\subsection{S. littoralis Differentially Catabolizes O. vulgare Terpenoids}

To evaluate the ability of $S$. littoralis to catabolize $O$. vulgare terpenoids, we analysed the terpenoid content of the frass of larvae (e.g., the insect excreted material) feeding on O. vulgare leaves (Table 1). The comparative analysis between leaf and frass terpenoids showed that many leaf O. vulgare volatiles were present in the insect frass and that the total terpenoid content was significantly reduced, indicating a high larval catabolic activity. In particular, the content of the major monoterpenes carvacrol, 
cis-sabinene hydrate, $\gamma$-terpinene and sabinene were significantly $(p<0.05)$ reduced in the frass, whereas most of the leaf monoterpenes and sesquiterpens were fully catabolized (Table 1).

\subsection{O. vulgare Terpenoids Modulate the Activity and Expression of S. littoralis Scavenging and} Detoxification Systems

In order to assess the potential scavenging responses of S. littoralis to O. vulgare terpenoids, we evaluated the insect's catalase (CAT), superoxide dismutase (SOD) and glutathione $S$-transferase (GST) enzyme activities (Figure 6). With respect to ACD, feeding on O. vulgare leaves significantly $(p<0.05)$ increased the CAT activity, whereas a significant increase in CAT activity was found only for $p$-cymene and $\gamma$-terpinene, when compared to ACD + Tween 20 (Figure 6A). SOD activity significantly $(p<0.05)$ increased with respect to both ACD and ACD + Tween 20 when larvae fed on both O. vulgare leaves and O. vulgare terpenes (Figure 6B). Finally, GST activity was only significantly $(p<0.05)$ increased in larvae feeding on $O$. vulgare leaves, not being significantly affected by the individual terpenes (Figure 6C).

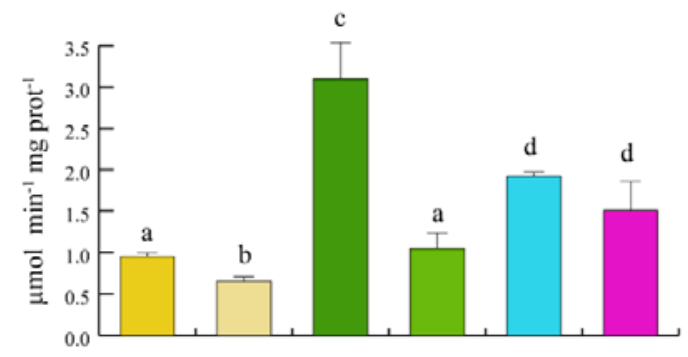

(A)

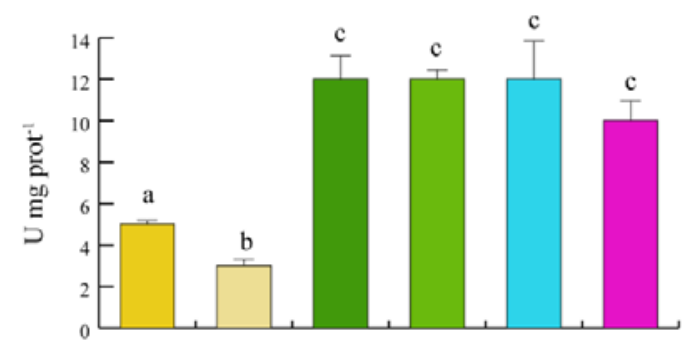

(B)

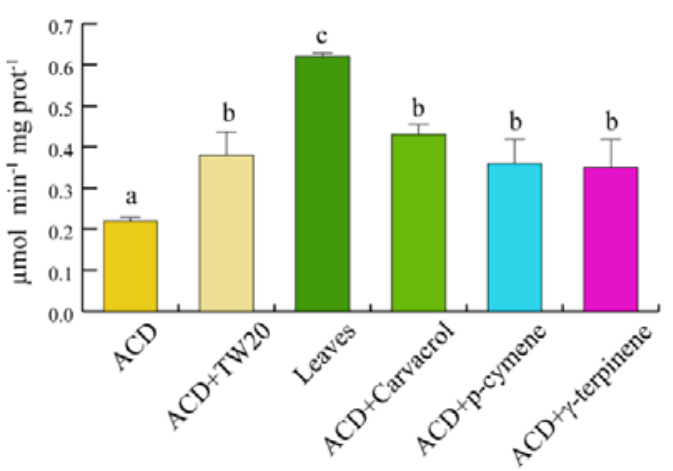

(C)

Figure 6. Antioxidant enzymes activities of $S$. littoralis after feeding on O. vulgare leaves and terpenoids. (A). Catalase (CAT) activity. (B). Superoxide dismutase (SOD) activity. (C). Glutathione S-transferase (GST) activity. Values are the mean of at least three replicates; metric bars indicate standard deviation. Different letters indicate significant $(p<0.05)$ differences. 
We then assessed the gene expression of the herbivore scavenging and detoxifying genes. $C A T$ expression was significantly upregulated when larvae fed on $O$. vulgare leaves, whereas no significant gene regulation was observed after feeding larvae with the individual terpenes (Figure 7A). $S O D$ gene expression was always upregulated, particularly after carvacrol feeding, in larvae feeding on both O. vulgare leaves and terpenoids (Figure 7B). Finally, a significant and consistent upregulation of GST was found when larvae fed on oregano leaves, whereas carvacrol and $\gamma$-terpinene significantly $(p<0.05)$ downregulated the larvae GST expression (Figure 7C).

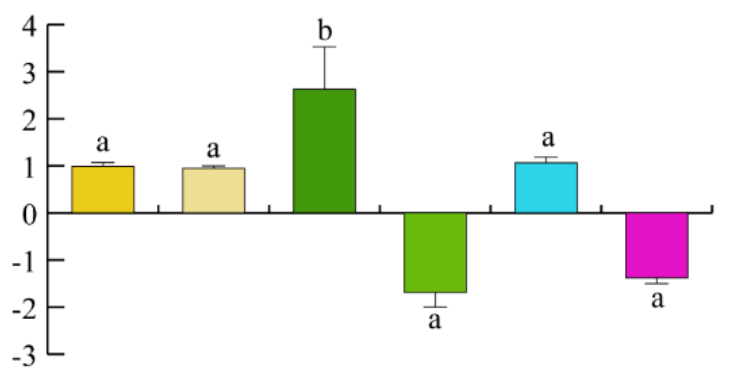

(A)

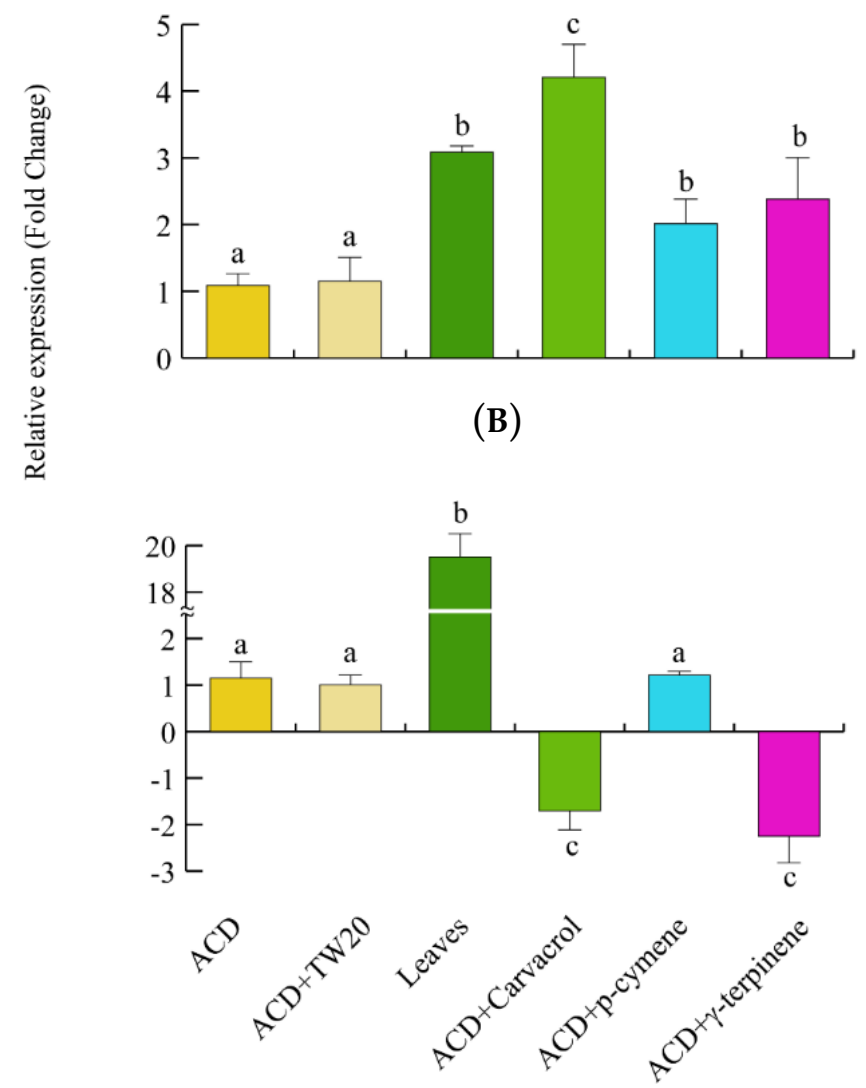

(C)

Figure 7. Levels of gene expression in S. littoralis upon feeding on O. vulgare with respect to those feeding on ACD or ACD + O. vulgare terpenoids (which is set to 1). (A). Catalase (CAT). (B). Superoxide dismutase $(S O D)$. (C); Glutathione $S$-transferase (GST). Values are the mean of at least three replicates; metric bars indicate standard deviation. Different letters indicate significant $(p<0.05)$ differences. 


\section{Discussion}

Terpenoids stored in the secretory structures of aromatic plants act as direct defense against herbivores, particularly against generalist insects $[13,28]$ and despite their constitutive nature, terpenoids can be modulated by herbivory [29-32]. In this work, we showed that feeding S. littoralis on O. vulgare leaves caused both the chemical and genetic modulation of the plant terpenoids. However, this modulation was mainly quantitative, because no qualitative changes were found in the terpenoids, with respect to control plants. In the interaction between the specialist Chrisolina herbacea and its host plant Mentha acquatica, terpenoid qualitative changes were observed upon herbivory [29]. Therefore, our results confirm the hypothesis that generalist and specialist herbivores may activate different plant responses [27]. The feeding activity of the generalist $S$. littoralis increased the expression of O. vulgare $D X S$, a gene involved in the early steps of terpenoid biosynthesis for the mevalonate-independent (MEP)-pathway gene, the product of which is considered to catalyze one of the rate-limiting steps of this pathway [33] as well as GPPS, whose overproduction is expected to result in increased production of monoterpene end products [34]. Upregulation of both DXS and GPPS correlated with the increased content of terpenoids upon herbivory. It is interesting to note that the specialist $C$. herbacea was unable to regulate the expression of M. aquatica DXS [29]. Of particular relevance was the herbivore-induced upregulation of $\gamma$-terpinene synthase (TPS2) and CYP71D180. CYP71D180 belongs to the cytochrome P450 (CYP) monooxygenases and is involved in further modifications of $\gamma$-terpinene backbone to yield carvacrol [8]. The gene is modulated by methyl jasmonate and salicylic acid as well as by feeding of insects [10] and its modulation is associated with a corresponding expression of early terpenoid genes, like DXP [35]. TPS2 increased expression has been recently reported upon interaction of O. vulgare with a Myrmica ant [10] and confirms the modulation of this gene upon biotic attack. Besides terpenoids, qualitative differences were found in the production of some GLVs, which are considered typical wound-related VOCs [13,36-39]. Upon herbivory, a significant release of GLVs has been observed in several non-aromatic plants, such as lima bean [40], as well as in plants producing glandular trichomes like Monarda fistulosa [41] and tomato [39].

The toxicity of terpenoids toward herbivory has been widely documented [42] and the insecticidal effect of several monoterpenes has been demonstrated in many species belonging to the Lamiaceae family [43-46]. Several studies have evaluated the toxicity of plant terpenes by the use of essential oils. However, the essential oil does not reflect the natural composition of accumulated terpenes in the glandular trichomes since partial terpene recovery and thermal degradation can occur [47]. In our study we used intact leaves and terpenes extracted from O. vulgare leaves to perform toxicological tests and we exposed the caterpillars to physiological concentrations based on the quantity detected in O. vulgare leaves. Carvacrol and $p$-cymene were the most toxic terpenes among the tested monoterpenes. These results are in agreement with the reported toxicity of carvacrol [48]. In a study on the toxicity of carvacrol and $p$-cymene towards $S$. littoralis, carvacrol resulted more active $\left(\mathrm{LD}_{25}=7 \mu \mathrm{g} \cdot \mathrm{larva}{ }^{-1}\right)$ with respect to $p$-cymene $\left(\mathrm{LD}_{25}=25 \mu \mathrm{g} \cdot \mathrm{larva}^{-1}\right)$ [17]. We also observed that the survival percentage of larvae upon carvacrol and $p$-cymene feeding was higher than larvae fed on leaves at the end of 3 rd stage. Toxicology studies on $S$. littoralis showed that the binary mixture of carvacrol and $p$-cymene have a synergic toxic effect if compared with the single compounds [17]. Therefore, similar synergistic effects can explain the lower toxicity of individual compounds with respect to O. vulgare leaves. Despite the known effects of thymol as an insecticide [49-51], no significant effects were observed in our study, probably because of the very low amount of thymol produced by the O. vulgare chemotype used in this study.

The inhibition of larval growth was mainly due to the presence of $\gamma$-terpinene, the biosynthetic precursor of carvacrol [8,52], whereas carvacrol and $p$-cymene did not affect significantly the larval growth. Although the topical application of a sub-lethal concentrations of carvacrol to $S$. littoralis has been demonstrated to exert a significant delay of larval development [16], feeding on carvacrol was found to be more tolerated by the insect, possibly by a different biodegradation/detoxification of this compound in the insect's gut. Since the growth rate, development lifespan, final body weight 
and survival percentages are strongly affected by the food intake and by the nutritional value of ingested food [53], it is conceivable that the larvae growth delay and reduced survival observed upon feeding on $O$. vulgare leaves might be correlated to both the deterrent and anti-nutritional effect of oregano terpenoids. Although the naïve larvae preferred the ACD during the choice tests, the presence of leaves as alternative food source appears to stimulate a higher feeding rate. In fact, larvae that experienced feeding on leaves selectively preferred $O$. vulgare leaves as nutritive source during the choice test. Our results also indicate a possible attractant effect mainly mediated by carvacrol and $\gamma$-terpinene [54,55]. Our data suggest that the continuous feeding on O. vulgare leaves significantly impairs the larvae growth (weight and size) and that this anti-nutritional effect is mainly mediated by $\gamma$-terpinene.

S. litura larvae are able to detoxify terpenes, including $\gamma$-terpinene [56-58]. The absence of chemical derivatives of $O$. vulgare terpenes and the assimilation of more than $50 \%$ of ingested terpenes by $S$. littoralis, as evidenced by our insect's frass analyses, show that $S$. littoralis catabolizes the plant terpenes and shows a limited ability to biotransform these molecules, in contrast to the typical behavior of specialist herbivores [59]. However, the catabolism of $O$. vulgare terpenes can also produce non-volatile derivatives which might have not been detected by our GC-MS and GC-FID analyses. Despite the absence of catabolic products, the insect response to ingestion of $O$. vulgare leaves was a significant increase of all tested enzyme activities. This increase was correlated to the presence of some O. vulgare monoterpenes only for CAT and SOD, whereas the increased GST activity was probably dependent on other leaf constituents or by the synergistic effect of the plant terpenoid blend. Increased oxidative stress is common in herbivore insects feeding on plants producing toxic allelochemicals. Insects like $S$. littoralis possess a suite of antioxidant enzymes such as CAT and SOD for protection against oxidative stress [60]. Insects also possess a GST which is effective in targeting hydroperoxides [61] and some terpenoid have the ability to modulate the activity of this enzyme [21]. For all tested enzymes and genes, there was a positive correlation between insect enzyme activity and gene expression upon feeding on leaves. In S. littoralis, a significant up-regulation of SOD, CAT and GST was shown upon feeding on a diet containing potato extracts showing that increased concentrations of antioxidants represent an herbivore defense against exogenous oxidative stress [62]. In agreement with the general hypothesis that increased oxidative stress may lead to a modulation of genes coding for antioxidant enzymes [62], we also found a positive correlation between SOD and CAT activity and gene expression upon feeding on selected monoterpenes. The enhanced activity of insect's SOD and CAT prevents oxidative damage and could depend on its secretion into the gut $[62,63]$. GST enzyme activity was not modulated by the selected terpenoids while its gene expression was downregulated by carvacrol and $\gamma$-terpinene. It is possible that the observed toxic effect of these monoterpenes may be partly depending on the reduced expression of GST. However, the contrasting results between the modulation exerted by feeding on leaves does not exclude the possibility that the regulation of this genes could be associated to other O. vulgare constituents such as phenolics [64-66]. It is known that some surfactants may interfere with enzyme activities [67]. Interestingly, the use of Tween-20 (which was essential for terpenoid solubilization) affected the enzyme activities of all tested enzymes.

\section{Materials and Methods}

\subsection{Plant and Animal Material}

Origanum vulgare L. (Lamiaceae) plants were propagated from stem cuttings provided by the University of Turin (Italy) Botanical Garden and grown with fluorescent lamps $\left(200 \mu \mathrm{mol} \cdot \mathrm{m}^{-2} \cdot \mathrm{s}^{-1}\right)$ with a light/darkness photoperiod of $16 / 8 \mathrm{~h}, 60 \%$ humidity at a temperature of $22^{\circ} \mathrm{C} \pm 2{ }^{\circ} \mathrm{C}$. Spodoptera littoralis Boisd. (Lepidoptera, Noctuidae) were kindly supplied as egg clutches by Syngenta Crop, Protection Münchwilen AG (Stein, Switzerland). Larvae were reared in plastic Petri dishes with the 
artificial diets as specified below, at $25^{\circ} \mathrm{C}, 60 \%$ relative humidity and a light/darkness photoperiod of $16 / 8 \mathrm{~h}$.

\subsection{Chemicals Used}

Carvacrol (95\%), p-cymene (95\%), thymol (95\%) and $\gamma$-terpinene (95\%), were purchased from TCI-EUROPE (Belgium). The chemical standards were properly diluted in water with the addition of $0.1 \% w / v$ Tween 20 (polyoxy ethylene sorbitan monolaurate, Sigma-Aldrich, Milan, Italy).

\subsection{Extraction of O. vulgare Terpenoids}

O. vulgare terpenoids were extracted from $20 \mathrm{~g}$ leaves with $70 \%$ ethanol (Sigma-Aldrich, USA) with a $1: 40 w / v$ ratio. Extraction was performed overnight in the dark at $22{ }^{\circ} \mathrm{C}$ and then in a sonic bath for $30 \mathrm{~min}$ at $22{ }^{\circ} \mathrm{C}$. The extract was filtered with cheese cloth and the leaves were re-extracted in a mortar with $70 \%$ ethanol. The extract was then filtered and both filtrates were combined and centrifuged for $10 \mathrm{~min}$ at $4000 \times g$ to remove plant residues. Terpenoids were then separated by liquid/liquid extraction $(1: 1 v / v)$ in a separation funnel with a mixture of 4:1 $v / v$ hexane:pentane (Carlo Erba, Milan, Italy). The liquid/liquid extraction was repeated twice. The extract was concentrated under vacuum by Centrivap concentrator (Labconco, Kansas City, MO, USA) at $35^{\circ} \mathrm{C}$ and then reduced to $3 \mathrm{~mL}$ by a constant flow of nitrogen.

\subsection{Artificial Diet Composition}

The artificial control diet (ACD) was composed of $125 \mathrm{~g}$ dry kidney beans, $2.25 \mathrm{~g}$ ascorbic acid (Sigma-Aldrich, Milan, Italy), $2.25 \mathrm{~g}$ ethyl hydroxybenzoate (Fluka, Milan, Italy), $750 \mu \mathrm{L}$ formaldehyde (Fluka), $10 \mathrm{~g}$ plant agar (Duchefa, Haarlem, The Netherland) and $600 \mathrm{~mL}$ water. The artificial diet was stored at $-20^{\circ} \mathrm{C}$ until use. The ACD was supplemented with O. vulgare extracted terpenes, carvacrol, $p$-cymene and $\gamma$-terpinene with the addition of $0.1 \% w / v$ Tween 20 . To avoid thermal degradation and volatilization of terpenes, the ACD was cooled down to $40^{\circ} \mathrm{C}$ before the addition of the aforementioned terpenes and terpenoid extract. Terpenes were added to the diet in quantities comparable to those detected in the leaves eaten by the caterpillars (i.e., the amounts described in Table 1).

\subsection{Terpene Toxicity Assays}

Toxicological experiments were carried out from the 2nd instar until the end of the 3rd instar of S. littoralis larvae reared on the ACD. Each caterpillar was moved into a new Petri dish and daily fed with either O. vulgare leaves (by using ACD as a control) or ACD supplemented with the terpenes (by using ACT + Tween 20 as a control). The daily supply of diet or leaves was calculated on larvae instars (80 and $150 \mathrm{mg}$ for the 2nd and 3rd instar, respectively). For each biological test, 15 biological replicates were run. During treatments, the survival percentage, larvae size and larvae weight were daily monitored. Larvae length was calculated with the use of ImageJ image software (NIH, Bethesda, ND, USA).

\subsection{Leaf Disk Choice Tests}

Choice tests were conducted using 3rd instar larvae starved for $17 \mathrm{~h}$ before tests. The assay time was $6 \mathrm{~h}$ and for each test 15 biological replicates were run. Tests were carried out in square plastic Petri dishes $(12 \mathrm{~cm} \times 12 \mathrm{~cm})$ where $O$. vulgare leaf disks or ACD plus terpenes were alternated with $\mathrm{ACD}$ pieces of similar area $\left(1.7 \mathrm{~cm}^{2}\right)$ on a $10 \times 10 \mathrm{~cm}$ grid (see Supplementary Figure S1). At the beginning of the test, one S. littoralis larva was placed in the center of the grid. The Petri dishes were covered with black mosquito net to reduce the light exposure as suggested by Carroll et al. [68]. We tested either naïve larvae that were fed only with ACD until bioassays or experienced larvae which were exposed, the previous day, to O. vulgare leaves or ACD plus terpenes. At the end of each bioassay, 
the percentage of eaten feed was calculated and the weight loss due to water evaporation was assessed in order to normalize the results of feeding preferences.

\subsection{S. littoralis Feeding on O. vulgaris Leaves}

Overnight starved 3rd instar S. littoralis larvae were placed on O. vulgare branches. After $24 \mathrm{~h}$, the caterpillars were removed and the herbivore damaged leaves were immediately collected and stored at $-20^{\circ} \mathrm{C}$ until extraction. Undamaged $O$. vulgare leaves were used as control.

$150 \mathrm{mg}$ herbivore-wounded (HW) O. vulgare leaves and controls were extracted in a glass tube with $3 \mathrm{~mL}$ 2:1 hexane/diethyl ether (Carlo Erba, Milan, Italy). Twenty $\mu \mathrm{g}$ pulegone (TCI Europe N.V., Zwijndrecht, Belgium) were added as internal standard.

S. littoralis frass was collected from 3rd instar caterpillars feeding on O. vulgare leaves. Samples were collected, weighted and stored at $-20^{\circ} \mathrm{C}$ until use. The experiment was performed in triplicate. One hundred $\mathrm{mg}$ frass were extracted with a pestle in a glass tube with $3 \mathrm{~mL}$ of 2:1 hexane/diethyl ether by using $20 \mu \mathrm{g}$ pulegone as internal standard. The frass extract was then placed in an ultrasonic water bath at room temperature for $30 \mathrm{~min}$ and then centrifuged at $4000 \times g$ for $5 \mathrm{~min}$ and the supernatant dehydrated in a glass column packed with anhydrous $\mathrm{MgSO}_{4}$ (Fluka, Milan, Italy). The extract was then concentrated by a constant flow of nitrogen $\left(\mathrm{N}_{2}\right)$ to $250 \mu \mathrm{L}$ before GC-MS and GC-FID analysis.

\subsection{Qualitative and Quantitative Analyses of O. vulgare Leaves and S. littoralis Frass Terpenoids}

Qualitative and quantitative analyses of volatile compounds in O. vulgare leaves and caterpillar frass were performed by GC-MS and GC-FID, respectively. GC-MS was performed with an Agilent $6890 \mathrm{~N}$ gas chromatograph coupled to an Agilent 5973A mass spectrometer by using a ZEBRON ZB-WAX column (30 m length, $250 \mu \mathrm{m}$ diameter, $0.25 \mu \mathrm{m}$ thickness) (Phenomenex, Torrance, CA, USA). Helium was used as carrier gas at constant flow of $1 \mathrm{~mL} \cdot \mathrm{min}^{-1}$. The following temperature program was used: $50^{\circ} \mathrm{C}$ as initial temperature, thermal gradient of $2{ }^{\circ} \mathrm{C} \min ^{-1}$ up to $190^{\circ} \mathrm{C}$ and then at $15^{\circ} \mathrm{C}$ $\mathrm{min}^{-1}$ up to $250^{\circ} \mathrm{C}$. Post time lasted $2 \mathrm{~min}$ at $250^{\circ} \mathrm{C}$. Injector port was set at $250{ }^{\circ} \mathrm{C}$ in splitless mode. Transfer line temperature to MSD was $280^{\circ} \mathrm{C}$ and ionization energy (EI) was $70 \mathrm{eV}$. Mass spectra were acquired in full scan mode with a 50-350 $\mathrm{m} / \mathrm{z}$ range. The identification of compounds was based on the comparison of their mass spectra with NIST 98 by the NIST v2.0 research software (Standard Reference Data, Gaithersburg, MD, USA) comparison of retention indices from apposite literature papers $[69,70]$ and pure standards. GC-FID quantitative analyses were performed on an Agilent 6890N gas chromatograph coupled to an FID at the same conditions as described above.

\subsection{Isolation of Total RNA and Expression of O. vulgare Genes in Response to S. littoralis Herbivory}

To evaluate the effect of $S$. littoralis herbivory on $O$. vulgare terpenoid metabolism, we analyzed the expression level of terpene synthases and cytochrome P450s previously known to be involved in the production of the main O. vulgare terpenoids $[8,10,35]$. Total RNA was extracted from $50 \mathrm{mg}$ of O. vulgare leaves after $6 \mathrm{~h}$ S. littoralis feeding and control unwounded leaves using the Agilent Plant RNA Isolation Mini Kit (Agilent Technologies, Santa Clara, CA, USA). To remove residual genomic DNA, RNA was treated with RNAse-free DNAse I set (Qiagen, Venio, The Netherlands). RNA quality was checked using the Agilent 2100 Bioanalyzer with RNA 6000 Nano LabChip. Quantitative analysis was performed using the Nano Drop ND-1000 micro-scale spectrophotometer (Thermo Fisher Scientific, Wilmington, DE, USA). For cDNA synthesis, high-capacity cDNA Reverse Transcription Kit (Applied Biosystems, Foster City, CA, USA) was used according to manufacturer's instructions. Reactions were prepared by adding $1.5 \mu \mathrm{g}$ total RNA, $2 \mu \mathrm{L}$ of $10 \times$ RT Buffer, $0.8 \mu \mathrm{L}$ of $25 \times$ dNTPs mix $(100 \mathrm{mM})$, $2 \mu \mathrm{L} 10 \times \mathrm{RT}$ primer, $1 \mu \mathrm{L}$ of Multiscribe ${ }^{\mathrm{TM}}$ Reverse Transcriptase and nuclease-free sterile water up to $20 \mu \mathrm{L}$. Reaction mixtures were incubated at $25^{\circ} \mathrm{C}$ for $10 \mathrm{~min}, 37^{\circ} \mathrm{C}$ for $2 \mathrm{~h}$, and $85^{\circ} \mathrm{C}$ for $5 \mathrm{~s}$. Samples were stored at $-20^{\circ} \mathrm{C}$ for further analyses. Primer pairs for the selected genes were designed using BeaconDesigner (version 5.0; PremierBiosoft, Palo Alto, CA, USA). Primers were designed 
for regions with the largest possible difference between the P450 sequences whilst primer binding sites were chosen for identical regions of all known alleles for the respective genes from O. vulgare and Thymus vulgaris. Each primer pair was tested for potential cross-hybridisation with the other P450s as templates; none was observed at a $60^{\circ} \mathrm{C}$ annealing temperature except that the CYP71D179 primers cross-reacted to some extent with the CYP79D178 and D182 sequences due to their close sequence similarities. Primers are listed in Supplementary Table S1. Primer efficiencies for all pairs were calculated using the standard curve method [71].

qPCR analysis was on a Stratagene Mx3000P Real-Time System (La Jolla, CA, USA) using SYBR green I with ROX as internal loading standard, using $10 \mu \mathrm{L}$ of mixture consisting of $5 \mu \mathrm{L} 2 \mathrm{X}$ MaximaTM SYBR Green qPCR Master Mix (Fermentas, Waltham, MA, USA), $0.6 \mu \mathrm{L}$ cDNA and $300 \mathrm{nM}$ primers (Integrated DNA Technologies, Skokie, IL, USA). Controls included non-RT controls (using total RNA without reverse transcription to monitor genomic DNA contamination) and non-template controls (water template). PCR conditions were: $10 \mathrm{~min}$ at $95^{\circ} \mathrm{C}, 40$ cycles of $15 \mathrm{~s}$ at $95^{\circ} \mathrm{C}, 20 \mathrm{~s}$ at $60^{\circ} \mathrm{C}, 30 \mathrm{~s}$ at $72{ }^{\circ} \mathrm{C}$. Fluorescence was read after each annealing and extension phase. All runs were followed by a melting curve analysis from 55 to $95^{\circ} \mathrm{C}$. The linear range of template concentration to threshold cycle value ( $C_{t}$ value) was determined by performing a dilution series using cDNA from three independent RNA extractions analyzed in three technical replicates. qPCR reactions were run using specific primers [52]. Three distinct reference genes: Elongation factor 1 alpha, actin and 18S rRNA were used to normalize the results of the real-time PCR. The most stable gene, selected using Normfinder software [72], was the elongation factor 1 alpha. All amplification plots were analyzed with MX3000P software (Agilent Technologies, Santa Clara, CA, USA) to obtain Ct values. Relative RNA levels were calibrated and normalized with the level of the elongation factor 1 alpha mRNA.

4.10. Isolation of Total RNA and Expression of S. littoralis Scavenging and Detoxifying Genes in Response to O. vulgare Terpenoids

Larvae were fed with ACD, ACD + Tween 20, ACD + O. vulgare terpenoids and O. vulgare leaves and were collected during the 3 rd instar.

Frozen larvae total RNA was isolated using Qiagen RNeasy Micro kit and RNase-Free DNase set to remove residual genomic DNA. Sample quality and quantity was checked by using the RNA 6000 Nano kit and Agilent 2100 Bioanalyzer and confirmed spectrophotometrically using a NanoDrop ND-1000. High-capacity cDNA Reverse Transcription Kit was used for cDNA synthesis. Reactions were prepared by adding $500 \mathrm{ng}$ total RNA and following the same protocol as described above. All qPCR experiments were performed on a Stratagene Mx3000P Real-Time System using SYBR green I with ROX as an internal loading standard. The reactions mixtures were prepared as above. PCR conditions were: Elongation factor $1(E F 1)$, actin $(A C T)$, catalase $(C A T)$, superoxide dismutase (SOD) and glutathione-S-transferase (GST): $10 \mathrm{~min}$ at $95^{\circ} \mathrm{C}, 45$ cycles of $15 \mathrm{~s}$ at $95{ }^{\circ} \mathrm{C}, 40 \mathrm{~s}$ at $52{ }^{\circ} \mathrm{C}$, and $30 \mathrm{~s}$ at $72{ }^{\circ} \mathrm{C}, 1 \mathrm{~min}$ at $95{ }^{\circ} \mathrm{C}, 30 \mathrm{~s}$ at $55^{\circ} \mathrm{C}, 30 \mathrm{~s}$ at $95^{\circ} \mathrm{C}$. Procedures for fluorescence reading, melting curve analysis and determination of the linear range of template concentration to $C t$ value were as described above.

qPCR reactions were run using specific primers designed on Genbank-available S. litura and S. exigua sequences using the Primer3 software [73] (Supplementary Table S2), with efficiencies for all pairs calculated as above. Two reference genes, $A C T$ and $E F 1$, were used to normalize results of the real time PCR, from which $A C T$ was selected as described above. $C t$ values of amplification plots and the calibration and normalization of relative RNA levels (using $A C T$ ) were as described above.

\subsection{S. littoralis Scavenging and Detoxifying Enzyme Activities upon Feeding on O. vulgare Terpenoids}

S. littoralis larvae at the transition between the 2 nd and the 3 rd instar were collected after 7 days feeding on the required diet and were immediately homogenized in $1 \mathrm{~mL}$ ice-cold $50 \mathrm{mM}$ potassium phosphate $\mathrm{pH} 7.2$ containing $0.5 \mathrm{mM}$ EDTA and $10 \mathrm{mmol}$ protease inhibitor phenyl-methyl-sulfonyl 
fluoride according to Hermeslima et al. [74]. The homogenate was centrifuged at $1600 \times g$ for $30 \mathrm{~min}$ at $4{ }^{\circ} \mathrm{C}$, and the supernatant was stored at $-20^{\circ} \mathrm{C}$ for enzyme assays.

Catalase (EC 1.11.1.6) (CAT) activity was measured according to Vecera et al. [75] with a few modifications. Ten microliters of sample homogenate were mixed with $390 \mu \mathrm{L} 60 \mathrm{mM} \mathrm{K} \mathrm{PO}_{4}$ buffer ( $\mathrm{pH}$ 7.0) and poured into the glass cuvette. Then $400 \mu \mathrm{L} 21 \mathrm{mM} \mathrm{H}_{2} \mathrm{O}_{2}$ solution were added and mixed, and the decrease in absorbance at $240 \mathrm{~nm}$ was measured. CAT activity was expressed in $\mu$ mol of decomposed $\mathrm{H}_{2} \mathrm{O}_{2}$ per minute using the extinction coefficient of $39.4 \mathrm{M}^{-1} \cdot \mathrm{cm}^{-1}$.

Superoxide dismutase (EC 1.15.1.1) (SOD) activity was assayed according to Karthi and Shivakumar [76] with some modifications. The reaction mixture was prepared in $1 \mathrm{~mL}$ spectrophotometer cuvettes by using $50 \mathrm{mM}$ Tris- $\mathrm{HCl}$ and $10 \mathrm{mM}$ EDTA buffer (pH 8.2) and $15 \mu \mathrm{L}$ extract supernatant. The content was mixed and the final volume was adjusted $990 \mu \mathrm{L}$. The reaction was started with the addition of $10 \mu \mathrm{L} 30 \mathrm{mM}$ pyrogallol and the absorbance read at $440 \mathrm{~nm}$. One unit of total SOD activity was calculated as the amount of protein per milligram causing 50\% inhibition of pyrogallol autoxidation. The total SOD activity was expressed as units per milligram of protein.

Glutathione $S$-transferase (EC 2.5.1.18) (GST) activity was assayed according to Habig et al. [77] with some modifications. The reaction mixture was prepared in $1 \mathrm{~mL}$ spectrophotometer cuvettes by using $50 \mathrm{mM}$ Tris- $\mathrm{HCl}$ buffer (pH 7.5), $100 \mu \mathrm{L} 0.4 \mathrm{mM}$ 1-Chloro-2.4-dinitrobenzene and $100 \mu \mathrm{L}$ extract supernatant. The reaction was started with the addition of $100 \mu \mathrm{L} 4 \mathrm{mM}$ reduced glutathione and the absorbance read at $340 \mathrm{~nm}$. The GST activity was expressed as units per milligram of protein

\subsection{Soluble Protein Determination}

Soluble protein concentration was evaluated by the method of Bradford [78] using BSA as a standard.

\subsection{Statistical Analyses}

The proportion of survived larvae were statistically compared using a $z$ test. The overall data sets are expressed as mean values of at least three biological replicates, using metric bars to indicate SD. Significance of differences observed in data sets was tested by ANOVA and then by the non-parametric Bonferroni and Tukey post-hoc test using the software SYSTAT 10 (SPSS Inc., Hong Kong, China).

\section{Conclusions}

In conclusion, the data here reported showed an increased modulation of $O$. vulgare terpenoid biosynthesis and gene expression upon S. littoralis feeding. The herbivore-induced increased level of terpenoids (particularly carvacrol and $p$-cymene) interacts with the herbivore by decreasing larval survival and growth rate. The assimilation by $S$. littoralis of more than $50 \%$ of ingested terpenes correlates with the possible toxic effects of $O$. vulgare terpenoids. Carvacrol and $\gamma$-terpinene mediate the larval feeding preferences; however, the prolonged feeding on $O$. vulgare terpenoids (particularly on $\gamma$-terpinene) exerts relevant toxic effects on larval survival. The insect reacts to $O$. vulgare terpenoids by modulating its antioxidant enzymes activities and gene expression; however, this was found insufficient to sustain the $O$. vulgare terpenoid toxicity.

Supplementary Materials: Supplementary materials can be found at http:/ / www.mdpi.com/1422-0067/19/9/ 2805/s1.

Author Contributions: Conceptualization, M.E.M..; Methodology, M.E.M. and C.A.; Software, M.E.M. and C.A.; Validation, M.E.M. and C.A.; Formal Analysis, C.A.; Investigation, M.E.M. and C.A.; Resources, M.E.M.; Data Curation, M.E.M. and C.A.; Writing-Original Draft Preparation, M.E.M.; Writing-Review \& Editing, M.E.M. and C.A.; Visualization, M.E.M. and C.A.; Supervision, M.E.M.; Project Administration, M.E.M.; Funding Acquisition, M.E.M.

Funding: This work was supported by the University of Turin.

Acknowledgments: The authors are grateful to A. Occhipinti for technical support.

Conflicts of Interest: The authors declare no conflict of interest. 


\section{Abbreviations}

$\begin{array}{ll}\text { ACD } & \text { Artificial control diet } \\ \text { CAT } & \text { Catalase } \\ \text { CYP71D/179/180/181/182 } & \text { Cytochrome P450 isoforms } \\ \text { DXP } & \text { Deoxyxylulose phosphate synthase } \\ \text { GPPS } & \text { Geranyldiphosphate synthase } \\ \text { GST } & \text { Glutathione S-transferase } \\ \text { HIPVs } & \text { Herbivore-Induced Plant Volatiles } \\ \text { HW } & \text { Herbivore-wounded } \\ \text { SOD } & \text { Suoperoxide dismutase } \\ \text { TPS2 } & \gamma \text {-terpinene synthase }\end{array}$

\section{References}

1. Dudareva, N.; Klempien, A.; Muhlemann, J.K.; Kaplan, I. Biosynthesis, function and metabolic engineering of plant volatile organic compounds. New Phytol. 2013, 198, 16-32. [CrossRef] [PubMed]

2. Dudareva, N.; Negre, F.; Nagegowda, D.A.; Orlova, I. Plant volatiles: Recent advances and future perspectives. Crit. Rev. Plant Sci. 2006, 25, 417-440. [CrossRef]

3. Heil, M. Indirect defence via tritrophic interactions. New Phytol. 2008, 178, 41-61. [CrossRef] [PubMed]

4. Maffei, M. Sites of synthesis, biochemistry and functional role of plant volatiles. S. Afr. J. Bot. 2010, 76, 612-631. [CrossRef]

5. Chen, M.S. Inducible direct plant defense against insect herbivores: A. review. Insect Sci. 2008, 15, 101-114. [CrossRef]

6. Glas, J.J.; Schimmel, B.C.; Alba, J.M.; Escobar-Bravo, R.; Schuurink, R.C.; Kant, M.R. Plant glandular trichomes as targets for breeding or engineering of resistance to herbivores. Int. J. Mol. Sci. 2012, 13, 17077-17103. [CrossRef] [PubMed]

7. Fahn, A. Secretory-tissues in vascular plants. New Phytol. 1988, 108, 229-257. [CrossRef]

8. Crocoll, C.; Asbach, J.; Novak, J.; Gershenzon, J.; Degenhardt, J. Terpene synthases of oregano (Origanum vulgare L.) and their roles in the pathway and regulation of terpene biosynthesis. Plant Mol. Biol. 2010, 73, 587-603. [CrossRef] [PubMed]

9. Russo, M.; Galletti, G.C.; Bocchini, P.; Carnacini, A. Essential oil chemical composition of wild populations of italian oregano spice (Origanum vulgare ssp. Hirtum (link) ietswaart): A preliminary evaluation of their use in chemotaxonomy by cluster analysis. 1. Inflorescences. J. Agric. Food Chem. 1998, 46, 3741-3746.

10. Patricelli, D.; Barbero, F.; Occhipinti, A.; Bertea, C.M.; Bonelli, S.; Casacci, L.P.; Zebelo, S.A.; Crocoll, C.; Gershenzon, J.; Maffei, M.E.; et al. Plant defences against ants provide a pathway to social parasitism in butterflies. Proc. Biol. Sci. 2015, 282. [CrossRef] [PubMed]

11. Kanda, D.; Kaur, S.; Koul, O. A comparative study of monoterpenoids and phenylpropanoids from essential oils against stored grain insects: Acute toxins or feeding deterrents. J. Pest Sci. 2017, 90, 531-545. [CrossRef]

12. Furstenberg-Hagg, J.; Zagrobelny, M.; Bak, S. Plant defense against insect herbivores. Int. J. Mol. Sci. 2013, 14, 10242-10297. [CrossRef] [PubMed]

13. Holopainen, J.K.; Gershenzon, J. Multiple stress factors and the emission of plant vocs. Trends Plant Sci. 2010, 15, 176-184. [CrossRef] [PubMed]

14. Gols, R. Direct and indirect chemical defences against insects in a multitrophic framework. Plant Cell Environ. 2014, 37, 1741-1752. [CrossRef] [PubMed]

15. Lucas-Barbosa, D.; van Loon, J.J.; Dicke, M. The effects of herbivore-induced plant volatiles on interactions between plants and flower-visiting insects. Phytochemistry 2011, 72, 1647-1654. [CrossRef] [PubMed]

16. Hummelbrunner, L.A.; Isman, M.B. Acute, sublethal, antifeedant, and synergistic effects of monoterpenoid essential oil compounds on the tobacco cutworm, Spodoptera litura (lep., noctuidae). J. Agric. Food Chem. 2001, 49, 715-720. [CrossRef] [PubMed]

17. Pavela, R. Acute, synergistic and antagonistic effects of some aromatic compounds on the Spodoptera littoralis boisd. (lep., noctuidae) larvae. Ind. Crop. Prod. 2014, 60, 247-258. [CrossRef]

18. Pavela, R. Acute toxicity and synergistic and antagonistic effects of the aromatic compounds of some essential oils against Culex quinquefasciatus say larvae. Parasitol. Res. 2015, 114, 3835-3853. [CrossRef] [PubMed] 
19. Demirel, N.; Erdogan, C. Insecticidal effects of essential oils from labiatae and lauraceae families against cowpea weevil, Callosobruchus maculatus (f.) (coleoptera: Bruchidae) in stored pea seeds. Entomol. Appl. Sci. Lett. 2017, 4, 13-19.

20. Pavela, R.; Maggi, F.; Cianfaglione, K.; Bruno, M.; Benelli, G. Larvicidal activity of essential oils of five apiaceae taxa and some of their main constituents against Culex quinquefasciatus. Chem. Biodivers. 2018, 15. [CrossRef] [PubMed]

21. Kumrungsee, N.; Pluempanupat, W.; Koul, O.; Bullangpoti, V. Toxicity of essential oil compounds against diamondback moth, Plutella xylostella, and their impact on detoxification enzyme activities. J. Pest Sci. 2014, 87, 721-729. [CrossRef]

22. Wilson, J.A.; Isman, M.B. Influence of essential oils on toxicity and pharmacokinetics of the plant toxin thymol in the larvae of Trichoplusia ni. Can. Entomol. 2006, 138, 578-589. [CrossRef]

23. Kordali, S.; Usanmaz, A.; Bayrak, N.; Cakir, A. Fumigation of volatile monoterpenes and aromatic compounds against adults of Sitophilus granarius (L.) (coleoptera: Curculionidae). Rec. Nat. Prod. 2017, 11, 362-373.

24. Tak, J.H.; Isman, M.B. Penetration-enhancement underlies synergy of plant essential oil terpenoids as insecticides in the cabbage looper, Trichoplusia ni. Sci. Rep. 2017, 7. [CrossRef] [PubMed]

25. Yotavong, P.; Boonsoong, B.; Pluempanupat, W.; Koul, O.; Bullangpoti, V. Effects of the botanical insecticide thymol on biology of a braconid, Cotesia plutellae (kurdjumov), parasitizing the diamondback moth, Plutella xylostella 1. Int. J. Pest Manage. 2015, 61, 171-178. [CrossRef]

26. Shahriari, M.; Sahbzadeh, N.; Zibaee, A.; Khani, A.; Senthil-Nathan, S. Metabolic response of Ephestia kuehniella zeller (lepidoptera: Pyralidae) to essential oil of ajwain and thymol. Toxin Rev. 2017, 36, 204-209. [CrossRef]

27. Ali, J.G.; Agrawal, A.A. Specialist versus generalist insect herbivores and plant defense. Trends Plant Sci. 2012, 17, 293-302. [CrossRef] [PubMed]

28. Unsicker, S.B.; Kunert, G.; Gershenzon, J. Protective perfumes: The role of vegetative volatiles in plant defense against herbivores. Curr. Opin. Plant Biol. 2009, 12, 479-485. [CrossRef] [PubMed]

29. Zebelo, S.A.; Bertea, C.M.; Bossi, S.; Occhipinti, A.; Gnavi, G.; Maffei, M.E. Chrysolina herbacea modulates terpenoid biosynthesis of Mentha aquatica 1. PLoS ONE 2011, 6, e17195. [CrossRef]

30. Banchio, E.; Zygadlo, J.; Valladares, G.R. Quantitative variations in the essential oil of Minthostachys mollis (kunth.) griseb. In response to insects with different feeding habits. J. Agri. Food Chem. 2005, 53, 6903-6906. [CrossRef] [PubMed]

31. Ngxande-Koza, S.W.; Heshula, L.U.P.; Hill, M.P. Changes in chemical composition of essential oils from leaves of different Lantana camara L. (verbenaceae) varieties after feeding by the introduced biological control agent, Falconia intermedia distant (hemiptera: Miridae). Afr. Entomol. 2017, 25, 462-473. [CrossRef]

32. Tozin, L.R.D.; Marques, M.O.M.; Rodrigues, T.M. Herbivory by leaf-cutter ants changes the glandular trichomes density and the volatile components in an aromatic plant model. AoB Plants 2017, 9. [CrossRef] [PubMed]

33. Estevez, J.M.; Cantero, A.; Reindl, A.; Reichler, S.; Leon, P. 1-deoxy-d-xylulose-5-phosphate synthase, a limiting enzyme for plastidic isoprenoid biosynthesis in plants. J. Biol. Chem. 2001, 276, 22901-22909. [CrossRef] [PubMed]

34. Mahmoud, S.S.; Croteau, R.B. Strategies for transgenic manipulation of monoterpene biosynthesis in plants. Trends Plant Sci. 2002, 7, 366-373. [CrossRef]

35. Majdi, M.; Malekzadeh-Mashhady, A.; Maroufi, A.; Crocoll, C. Tissue-specific gene-expression patterns of genes associated with thymol/carvacrol biosynthesis in thyme (thymus vulgaris L.) and their differential changes upon treatment with abiotic elicitors. Plant Physiol. Biochem. 2017, 115, 152-162. [CrossRef] [PubMed]

36. Kessler, A.; Baldwin, I.T. Defensive function of herbivore-induced plant volatile emissions in nature. Science 2001, 291, 2141-2144. [CrossRef] [PubMed]

37. Maffei, M.E.; Mithoefer, A.; Boland, W. Insects feeding on plants: Rapid signals and responses preceding the induction of phytochemical release. Phytochemistry 2007, 68, 2946-2959. [CrossRef] [PubMed]

38. Wei, J.; Kang, L. Roles of (z)-3-hexenol in plant-insect interactions. Plant Signal. Behave. 2011, 6. [CrossRef]

39. Zebelo, S.A.; Matsui, K.; Ozawa, R.; Maffei, M.E. Plasma membrane potential depolarization and cytosolic calcium flux are early events involved in tomato (Solanum lycopersicum) plant-to-plant communication. Plant Sci. 2012, 196, 93-100. [CrossRef] [PubMed] 
40. Arimura, G.I.; Koepke, S.; Kunert, M.; Volpe, V.; David, A.; Brand, P.; Dabrowska, P.; Maffei, M.E.; Boland, W. Effects of feeding Spodoptera littoralis on lima bean leaves: Iv. Diurnal and nocturnal damage differentially initiate plant volatile emission. Plant Physiol. 2008, 146, 965-973. [CrossRef] [PubMed]

41. Keefover-Ring, K. Making scents of defense: Do fecal shields and herbivore-caused volatiles match host plant chemical profiles? Chemoecology 2013, 23, 1-11. [CrossRef]

42. Bakkali, F.; Averbeck, S.; Averbeck, D.; Waomar, M. Biological effects of essential oils-A review. Food Chem. Toxicol. 2008, 46, 446-475. [CrossRef] [PubMed]

43. Isman, M.B.; Wilson, J.A.; Bradbury, R. Insecticidal activities of commercial rosemary oils (Rosmarinus officinalis) against larvae of Pseudaletia unipuncta and Trichoplusia ni in relation to their chemical compositions. Pharm. Biol. 2008, 46, 82-87. [CrossRef]

44. Khani, A.; Asghari, J. Insecticide activity of essential oils of Mentha longifolia, Pulicaria gnaphalodes and Achillea wilhelmsii against two stored product pests, the flour beetle, Tribolium castaneum, and the cowpea weevil, Callosobruchus maculatus. J Insect Sci. 2012, 12. [CrossRef] [PubMed]

45. Khater, K.S.; El-Shafiey, S.N. Insecticidal effect of essential oils from two aromatic plants against Tribolium castaneum (herbst), (coleoptera: Tenebrionidae). Egypt. J. Biol. Pest Co. 2015, 25, 129-134.

46. Jassbi, A.R.; Zare, S.; Firuzi, O.; Xiao, J.B. Bioactive phytochemicals from shoots and roots of salvia species. Phytochem. Rev. 2016, 15, 829-867. [CrossRef]

47. Zheljazkov, V.D.; Astatkie, T.; Schlegel, V. Distillation time changes oregano essential oil yields and composition but not the antioxidant or antimicrobial activities. HortScience 2012, 47, 777-784.

48. Koul, O.; Singh, R.; Kaur, B.; Kanda, D. Comparative study on the behavioral response and acute toxicity of some essential oil compounds and their binary mixtures to larvae of Helicoverpa armigera, Spodoptera litura and Chilo partellus. Ind. Crop. Prod. 2013, 49, 428-436. [CrossRef]

49. Oliveira, A.P.; Santos, A.A.; Santana, A.S.; Lima, A.P.S.; Melo, C.R.; Santana, E.D.R.; Sampaio, T.S.; Blank, A.F.; Araujo, A.P.A.; Cristaldo, P.F.; et al. Essential oil of Lippia sidoides and its major compound thymol: Toxicity and walking response of populations of Sitophilus zeamais (coleoptera: Curculionidae). Crop Prot. 2018, 112, 33-38. [CrossRef]

50. Pavela, R.; Sedlak, P. Post-application temperature as a factor influencing the insecticidal activity of essential oil from thymus vulgaris. Ind. Crop. Prod. 2018, 113, 46-49. [CrossRef]

51. Webster, A.E.; Manning, P.; Sproule, J.M.; Faraone, N.; Cutler, G.C. Insecticidal and synergistic activity of two monoterpenes against diamondback moth (lepidoptera: Plutellidae). Can. Entomol. 2018, 150, 258-264. [CrossRef]

52. Poulose, A.J.; Croteau, R. Biosynthesis of aromatic monoterpenes: Conversion of gamma-terpinene to p-cymene and thymol in Thymus vulgaris 1. Arch. Biochem. Biophys. 1978, 187, 307-314. [CrossRef]

53. Martinez, S.S.; Van Emden, H.F. Sublethal concentrations of azadirachtin affect food intake, conversion efficiency and feeding behaviour of Spodoptera littoralis (lepidoptera: Noctuidae). B. Entomol. Res. 1999, 89, 65-71. [CrossRef]

54. Akhtar, Y.; Rankin, C.H.; Isman, M.B. Decreased response to feeding deterrents following prolonged exposure in the larvae of a generalist herbivore, Trichoplusia ni (lepidoptera: Noctuidae). J. Insect Behav. 2003, 16, 811-831. [CrossRef]

55. Hanley, M.E.; Lamont, B.B.; Fairbanks, M.M.; Rafferty, C.M. Plant structural traits and their role in anti-herbivore defence. Perspect. Plant Ecol. 2007, 8, 157-178. [CrossRef]

56. Miyazawa, M.; Murata, T. Biotransformation of myrcene by the larvae of common cutworm (Spodoptera litura). J. Agri. Food Chem. 2000, 48, 123-125. [CrossRef]

57. Miyazawa, M.; Wada, T.; Kameoka, H. Biotransformation of gamma terpinene in common cutworm larvae (Spodoptera litura fabricius). J. Agri. Food Chem. 1996, 44, 2889-2893. [CrossRef]

58. Miyazawa, M.; Wada, T. Biotransformation of terpinene and phellandrene by the larvae of common cutworm (Spodoptera litura). J. Agri. Food Chem. 2000, 48, 2893-2895. [CrossRef]

59. Cordero, C.; Zebelo, S.A.; Gnavi, G.; Griglione, A.; Bicchi, C.; Maffei, M.E.; Rubiolo, P. Hs-SPME-GCXGCQMS volatile metabolite profiling of Chrysolina herbacea frass and mentha spp. Leaves. Anal. Bioanal. Chem. 2012, 402, 1941-1952. [CrossRef] [PubMed]

60. Felton, G.W.; Summers, C.B. Antioxidant systems in insects. Arch. Insect Biochem. 1995, 29, $187-197$. [CrossRef] [PubMed] 
61. Ahmad, S. Biochemical defense of prooxidant plant allelochemicals by herbivorous insects. Biochem. Syst. Ecol. 1992, 20, 269-296. [CrossRef]

62. Krishnan, N.; Kodrik, D. Antioxidant enzymes in Spodoptera littoralis (boisduval): Are they enhanced to protect gut tissues during oxidative stress? J. Insect Physiol. 2006, 52, 11-20. [CrossRef] [PubMed]

63. Krishnan, N.; Sehnal, F. Compartmentalization of oxidative stress and antioxidant defense in the larval gut of spodoptera littoralis. Arch. Insect Biochem. 2006, 63, 1-10. [CrossRef] [PubMed]

64. Anshul, N.; Bhakuni, R.S.; Gaur, R.; Singh, D. Isomeric flavonoids of Artemisia annua (asterales: Asteraceae) as insect growth inhibitors against Helicoverpa armigera (lepidoptera: Noctuidae). Fla. Entomol. 2013, 96, 897-903. [CrossRef]

65. Hoffmann-Campo, C.B.; Harborne, J.B.; McCaffery, A.R. Pre-ingestive and post-ingestive effects of soya bean extracts and rutin on Trichoplusia ni growth. Entomol. Exp. Appl. 2001, 98, 181-194. [CrossRef]

66. Klopman, G.; Venegas, R.E. Computer automated structure evaluation (case) of flavonoids as larval growth-inhibitors. Pure Appl. Chem. 1988, 60, 265-270. [CrossRef]

67. Ghashghaei, T.; Soudi, M.R.; Hoseinkhani, S.; Shiri, M. Effects of nonionic surfactants on xanthan gum production: A survey on cellular interactions. Iran. J. Biotechnol. 2018, 16, 60-66. [CrossRef]

68. Carroll, M.; Schmelz, E.; Meagher, R.; Teal, P. Attraction of spodoptera frugiperda larvae to volatiles from herbivore-damaged maize seedlings. J. Chem. Ecol. 2006, 32, 1911-1924. [CrossRef] [PubMed]

69. Davies, N.W. Gas-chromatographic retention indexes of monoterpenes and sesquiterpenes on methyl silicone and carbowax 20m phases. J. Chromatogr. 1990, 503, 1-24. [CrossRef]

70. Goodner, K. Practical retention index models of OV-101, DB-1, DB-5, and Db-wax for flavor and fragrance compounds. Lwt-Food Sci. Techn. 2008, 41, 951-958. [CrossRef]

71. Pfaffl, M.W. A new mathematical model for relative quantification in real-time RT-PCR. Nucl. Acids Res. 2001, 29. [CrossRef]

72. Andersen, C.L.; Jensen, J.L.; Orntoft, T.F. Normalization of real-time quantitative reverse transcription-PCR data: A model-based variance estimation approach to identify genes suited for normalization, applied to bladder and colon cancer data sets. Cancer Res. 2004, 64, 5245-5250. [CrossRef] [PubMed]

73. Rozen, S.; Skaletsky, H. Primer3 on the www for general users and for biologist programmers. In Bioinformatics Methods and Protocols; Krawetz, S., Misener, S., Eds.; Humana Press: Totowa, NJ, USA, 2000; pp. 365-386.

74. Hermeslima, M.; Willmore, W.G.; Storey, K.B. Quantification of lipid-peroxidation in tissue-extracts based on Fe (III) xylenol orange complex-formation. Free Radic. Biol. Med. 1995, 19, 271-280. [CrossRef]

75. Vecera, J.; Krishnan, N.; Mithofer, A.; Vogel, H.; Kodrik, D. Adipokinetic hormone-induced antioxidant response in Spodoptera littoralis. Comp. Biochem. Physiol. C 2012, 155, 389-395.

76. Karthi, S.; Shivakumar, M.S. The protective effect of melatonin against cypermethrin-induced oxidative stress damage in Spodoptera litura (lepidoptera: Noctuidae). Biol. Rhythm Res. 2015, 46, 1-12. [CrossRef]

77. Habig, W.H.; Pabst, M.J.; Jakoby, W.B. Glutathione s-transferases. The first enzymatic step in mercapturic acid formation. J. Biol. Chem. 1974, 249, 7130-7139. [PubMed]

78. Bradford, M.M. A rapid and sensitive method for the quantitation of microgram quantities of protein utilizing the principle of protein-dye binding. Anal. Biochem. 1976, 72, 248-254. [CrossRef]

(C) 2018 by the authors. Licensee MDPI, Basel, Switzerland. This article is an open access article distributed under the terms and conditions of the Creative Commons Attribution (CC BY) license (http://creativecommons.org/licenses/by/4.0/). 